\title{
INFLUENCE OF EXERCISE ON PATIENTS WITH CORONARY HEART DISEASE
}

\author{
A INFLUÊNCIA DO EXERCÍCIO EM PACIENTES COM DOENÇA ARTERIAL CORONARIANA \\ LA INFLUENCIA DEL EJERCICIO EN PACIENTES CON ENFERMEDAD ARTERIAL CORONARIA
}

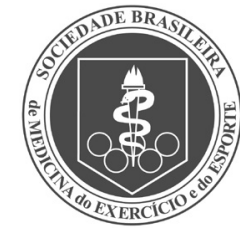

Original Article

ARtigo Original

Artículo Original

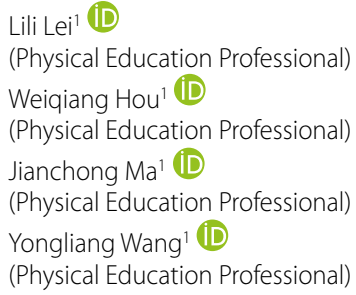

(Physical Education Professional)

Weiqiang Hou' (DD

(Physical Education Professional)

Jianchong $\mathrm{Ma}^{1}$ (D)

(Physical Education Professional)

Yongliang Wang 1 (DD

(Physical Education Professional)

1. Physical Education Teaching and Research Office, Shijiazhuang People's Medical College,

Shijiazhuang, China.

\section{Correspondence:}

Weiqiang Hou. Shijiazhuang, China. 050000.

hwq13739783676@163.com

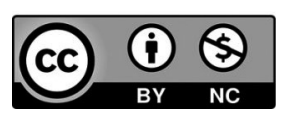

\begin{abstract}
Introduction: Coronary heart disease refers to coronary atherosclerosis caused by various reasons. Objective: To study the effect of acupuncture combined with exercise on patients with coronary heart disease after $\mathrm{PCl}$ (percutaneous coronary intervention). Methods: 50 patients with high blood pressure were selected. Patients in group $A$ received regular medication and health education. Patients in group B received acupuncture and exercise. Results: After 12 weeks of exercise and therapy, the patient's physical parameters improved. The CPET index increased, but the peak value of VENCO2 decreased. The difference was statistically significant (ALL P $<0.05$ ). Conclusion: Compared with simple exercise training, combining acupuncture and exercise training can improve the cardiopulmonary function and exercise ability of middle-aged and elderly patients with coronary heart disease after $\mathrm{PCl}$. It has a better effect on improving patients> physical pain, energy, emotional function, and mental health than simple exercise training. Level of evidence II; Therapeutic studies - investigation of treatment results.
\end{abstract}

Keywords: Coronary Artery Disease; Sports; Acupuncture.

\section{RESUMO}

Introdução: A expressão doença arterial coronariana se refere à arteriosclerose coronariana, que tem diversas etiologias possiveis. Objetivo: Estudar o efeito da acupuntura combinada com exercícios em pacientes com doença arterial coronariana depois de IPC (intervenção percutânea coronariana). Métodos: 50 pacientes com pressão sanguínea alta foram selecionados e divididos em dois grupos. Pacientes do Grupo A receberam medicação típica e ensino voltado à saúde. Pacientes do Grupo B receberam acupuntura combinada com exercícios. Resultados: Depois de 12 semanas de atividade física e terapia, houve melhora nos parâmetros físicos dos pacientes. O índice CPET aumentou, mas o valor máximo de VENCCO2 diminuiu. A diferença foi estatisticamente significativa para todos $(p<0,05)$. Conclusão: Comparado ao treino que incluía apenas atividades físicas, a combinação desse tipo de treino com acupuntura pode melhorar a função cardiopulmonar e a capacidade física de pacientes idosos ou de meia idade com doença coronariana depois de uma IPC. Seu efeito benéfico é maior que o efeito da atividade física isolada em relação a dor física, energia, função emocional e saúde mental. Nível de evidência Il; Estudos terapêuticos - investigação do resultado de tratamentos.

Descritores: Doença da Artéria Coronariana; Esportes; Acupuntura.

\section{RESUMEN}

Introducción: La expresión enfermedad arterial coronaria se refiere a la arteriosclerosis coronaria, que tiene diversas etiologías posibles. Objetivo: Estudiar el efecto de la acupuntura combinada con ejercicios en pacientes con enfermedad arterial coronaria después de IPC (intervención percutánea coronaria). Métodos: Fueron seleccionados y divididos en dos grupos 50 pacientes con presión sanguínea alta. Los pacientes del Grupo A recibieron medicación típica y enseñanza dirigida a la salud. Los pacientes del Grupo B recibieron acupuntura combinada con ejercicios. Resultados: Después de 12 semanas de actividad física y terapia, hubo mejora en los parámetros físicos de los pacientes. El índice CPET aumentó, pero el valor máximo de VENCO2 disminuyó. La diferencia fue estadísticamente significativa para todos $(p<0,05)$. Conclusión: Comparado al entrenamiento que incluía solo actividades físicas, la combinación de este tipo de entrenamiento con acupuntura puede mejorar la función cardiopulmonary la capacidad física de pacientes ancianos o de media edad con enfermedad coronaria después de una IPC. Su efecto benéfico es mayor que el efecto de la actividad física aislada en relación al dolor físico, energía, función emocional y salud mental. Nivel de evidencia ll; Estudios terapéuticos - investigación del resultado de tratamientos.

Descriptores: Enfermedad de la Arteria Coronaria; Deportes; Acupuntura. 


\section{INTRODUCTION}

Coronary heart disease refers to atherosclerosis of the coronary arteries caused by a variety of causes, further leading to narrowing, spasm or blockage of the blood vessels, ultimately leading to myocardial ischemia, hypoxia or necrosis, referred to as coronary heart disease (CHD), which belongs to ischemic heart disease, is the most common type of organ function and morphological structure lesions caused by atherosclerosis. ${ }^{1} \mathrm{CHD}$ is one of the major diseases that seriously affect human health. According to The Report on Cardiovascular Diseases in China, the mortality rate of CHD in urban and rural Areas in China was 264.84/100,000 and 298.42/100,000 respectively in 2015, increasing year by year. ${ }^{2}$ The World Bank estimates that from 2010 to 2040, a 1 percent reduction in cardiovascular deaths in China would benefit $\$ 10.7$ trillion. Cardiovascular disease accounts for $30 \%$ of the leading causes of death globally, costing doctors over $\$ 2$ billion a year in services, hospital costs, lost wages and reduced productivity. ${ }^{3}$

Cardiopulmonary exercise test has a history of several decades in foreign countries and has become the classic standard for the formulation of exercise prescriptions. However, cardiopulmonary exercise test has just begun in China, and the use of cardiopulmonary exercise test to develop individual exercise prescriptions is rarely reported. Tuan $\mathrm{S}$ H's study proved that acupuncture at Neiguan Point can enhance the expression of heat shock protein in myocardial ischemic cells, reduce the release of oxygen free radicals and relieve the symptoms of myocardial ischemia. ${ }^{4}$ Meng-chun observed perioperative cardiac dynamic changes of CHD patients by embedding needle at Neiguan Qie Men point, and found significant decrease in ventricular arrhythmia and increase in stroke output and cardiac output, suggesting a relationship between the two. ${ }^{5}$

\section{METHOD}

\section{General Information}

From October 2019 to September 2020, 50 patients (3-12 months after surgery) who underwent $\mathrm{PCl}$ in cardiac rehabilitation clinic were enrolled. Inclusion criteria: In accordance with the Exercise Standards for Testing and Training published by the American Heart Association in 2013, NYHA cardiac function classification II - III, and can accept exercise therapy when the condition is stable. Exclusion criteria: 1) Chronic obstructive pulmonary disease (COPD), pulmonary embolism, deep vein thrombosis, stroke and other patients; 2) Severe arrhythmia combined with hemodynamic abnormalities; 3) Myocarditis, cardiomyopathy, severe liver and kidney dysfunction; 4) Language communication, hearing disorders, mental disorders affect communicators; 5) Have rheumatism or motor diseases, which affect normal training. ' Criteria for discontinuation: those who reject acupuncture and moxibustion treatment, or who cannot cooperate with doctors to complete treatment tasks due to various reasons. Grouping: 50 patients (aged 45-65 years) were randomly divided into two groups, with 25 patients in each group. group A was the exercise training group, group B was treated by screw acupuncture combined with exercise training group, and group C was control group, there were no significant differences in age, gender, body mass index (BMI), years of education and other general conditions among the three groups $(P>0.05){ }^{8}$

\section{Methods}

\section{(1) measurement of human parameters}

All subjects were measured for height, weight, neck circumference, waist circumference, hip circumference, and Body Mass Index (BMI), waist-to-hip ratio, recorded as baseline data. At 4 weeks, 8 weeks and 12 weeks, the test was repeated and compared, and the equipment was a scale, flexible ruler, etc. Neck circumference, waist circumference and hip circumference were measured as follows, three times in succession, recorded in $\mathrm{cm}(\mathrm{cm})$ and accurate to $0.1 \mathrm{~cm} .{ }^{9}$

\section{(2) Acupuncture treatment}

Group B was treated with screw acupuncture before exercise, Cleft, Xinshu, Feishu, Renshu and Sanyinjiao were selected for exercise training, patients were also asked to keep the needle until they fell asleep on the same day, and knead neiguan, QIEmen, Zusanli and Sanyinjiao acupoints. ${ }^{10}$

\section{Statistical Treatment}

All data were input into the database, and SPSS16.0 statistical analysis software was used for input and processing. The quantitative data were expressed as mean \pm standard deviation $(x \pm s)$, and the data were tested for normality and homogeneity of variance. Paired sample $T$ test was used for self-comparison before and after treatment. Taking $a=0.05$ as the test level, $\mathrm{P}<0.05$ indicated statistically significant difference.

\section{RESULTS}

Comparison of baseline data and physical parameters at 4, 8 and 12 weeks After exercise treatment, changes in BMI, neck circumference, waist circumference, hip circumference and waist-hip ratio are shown in Table 1.

\section{Cardiopulmonary function changes in each group}

FEV1, FEV1/FVC\% and MW in group A were significantly decreased $(\mathrm{P}<$ $0.05)$, LVEF and HRR1 were also decreased $(P>0.05)$. All indexes in group $A$ and $B$ were significantly improved $(P<0.01)$, and the improvement of LVEF and HRR1 in group $B$ was better than that in group $A(P<0.05)$. (Table 2$)$

\section{Changes in exercise ability in each group}

VO2max, AT and MWL were significantly decreased in group $A(P<$ $0.01)$, and all indexes were significantly improved in group $B(P<0.01)$, among which the improvement of $\mathrm{VO} 2$ max and $\mathrm{AT}$ in group $\mathrm{B}$ was better than that in group $A(P<0.05)$. (Table 3$)$

Table 1. Changes of body parameters before and after treatment.

\begin{tabular}{c|c|c|c|c|c}
\hline Indicators & BMI & $\begin{array}{c}\text { Neck } \\
\text { circumference }\end{array}$ & $\begin{array}{c}\text { Waist } \\
\text { circumference }\end{array}$ & $\begin{array}{c}\text { Hip } \\
\text { circumference }\end{array}$ & $\begin{array}{c}\text { Waist-to- } \\
\text { hip ratio }\end{array}$ \\
\hline $\begin{array}{c}\text { Baseline } \\
\text { data }\end{array}$ & $26.65 \pm 1.29$ & $36.15 \pm 1.31$ & $86.92 \pm 5.70$ & $97.25 \pm 3.86$ & $0.89 \pm 0.31$ \\
\hline 4 weeks & $26.07 \pm 1.31$ & $25.69 \pm 1.29$ & $85.18 \pm 5.47$ & $96.74 \pm 3.69$ & $0.88 \pm 0.30$ \\
\hline 8 weeks & $25.19 \pm 1.49$ & $35.45 \pm 1.28$ & $83.70 \pm 5.04$ & $95.83 \pm 3.46$ & $0.87 \pm 0.02$ \\
\hline 12 weeks & $24.52 \pm 1.54$ & $35.62 \pm 1.33$ & $81.98 \pm 4.69$ & $94.79 \pm 2.83$ & $0.86 \pm 0.03$ \\
\hline
\end{tabular}

Table 2. Cardiopulmonary function changes in each group.

\begin{tabular}{c|c|c|c}
\hline \multicolumn{2}{c|}{ Group } & Group A & Group B \\
\hline \multicolumn{2}{c}{ The number of cases } & $\mathbf{2 5}$ & $\mathbf{2 5}$ \\
\hline \multirow{2}{*}{ FEV1 } & Before the treatment & $1.91 \pm 0.11$ & $1.82 \pm 0.11$ \\
\cline { 2 - 4 } & After treatment & $1.79 \pm 0.13$ & $2.04 \pm 0.11$ \\
\hline \multirow{2}{*}{ FEV1/FVC\% } & Before the treatment & $76.3 \pm 5.1$ & $74.5 \pm 4.1$ \\
\cline { 2 - 4 } & After treatment & $70.2 \pm 4.2$ & $82.3 \pm 3.9$ \\
\hline \multirow{2}{*}{ MVV } & Before the treatment & $73.2 \pm 4.9$ & $71.2 \pm 5.1$ \\
\cline { 2 - 4 } & After treatment & $70.8 \pm 4.2$ & $76.8 \pm 5.2$ \\
\hline \multirow{2}{*}{ LVEF } & Before the treatment & $60.3 \pm 5.2$ & $61.3 \pm 4.1$ \\
\cline { 2 - 4 } & After treatment & $59.2 \pm 4.1$ & $66.2 \pm 3.2$ \\
\hline \multirow{2}{*}{ HRR1 } & Before the treatment & $7.25 \pm 2.65$ & $6.94 \pm 2.05$ \\
\cline { 2 - 4 } & After treatment & $6.85 \pm 3.55$ & $9.48 \pm 2.37$ \\
\hline
\end{tabular}

Table 3. Changes of exercise ability in each group.

\begin{tabular}{c|c|c|c}
\hline Group & & Group A & Group B \\
\hline The number of cases & & $\mathbf{2 5}$ & $\mathbf{2 5}$ \\
\hline VO2max & Before the treatment & $18.5 \pm 6.2$ & $19.2 \pm 5.4$ \\
\hline & After treatment & $16.7 \pm 5.5$ & $22.7 \pm 5.5$ \\
\hline AT & Before the treatment & $14.8 \pm 2.8$ & $15.3 \pm 3.5$ \\
\hline & After treatment & $12.3 \pm 2.5$ & $18.3 \pm 2.5$ \\
\hline MWL & Before the treatment & $91.5 \pm 26.8$ & $92.9 \pm 28.5$ \\
\hline & After treatment & $86.2 \pm 22.5$ & $122.2 \pm 29.7$ \\
\hline
\end{tabular}




\section{Changes in health status of each group}

The 8 dimensions in group A were decreased to varying degrees $(P<0.01)$, and the 8 dimensions in group $B$ were significantly improved $(\mathrm{P}<0.01)$, among which the improvement of $\mathrm{BP}, \mathrm{VT}, \mathrm{RE}$ and $\mathrm{MH}$ was better than that in group $A(P<0.05)$. (Figure 1)

\section{DISCUSSION}

In the resting state, the heart rate is regulated by both sympathetic and vagus nerves, which is mainly controlled by vagus nerves, the motor center rate cannot increase with the needs of body metabolism, or cannot be kept stable, which are the manifestations of cardiac dysfunctions. This study found that resting heart rate decreased and peak heart rate increased after exercise training, the possible mechanism being that exercise regulates the activities of sympathetic and vagus nerves, with increased exercise capacity, the body's metabolic needs can be met by a slow resting heart rate, which increases vagus nerve activity, after exercise training, patients' peak power increased, that is, their exercise ability was improved. When they completed higher power, their heart rate increased along with the power energy, sympathetic activity was improved, indicating that cardiac timing was also improved.

Exercise training to improve cardiopulmonary function has been widely recognized in a number of domestic and foreign studies. In this study, cardiac rehabilitation with exercise training as the core significantly improved cardiopulmonary function and exercise ability of patients with CHD after PCl. Exercise ability of middle-aged and elderly patients with CHD is particularly important, which is related to the quality of life and disease recovery of patients in later stage. Different from traditional ideas, middle-aged and elderly people, whether exercise endurance, cardiopulmonary function or muscle strength, still have very good plasticity, should be fully utilized. Cardiac rehabilitation with exercise training as the core can improve the quality of life of patients evaluated by the SF-36 Brief Health Status Scale. As an auxiliary treatment, acupuncture has been widely used in coronary heart disease. Acupuncture and moxibustion is equally effective for pain and discomfort caused by simple sports injuries, it can increase the absorption of local inflammatory factors, accelerate the absorption and elimination of inflammatory edema, and achieve the purpose of relieving muscle spasm, swelling and pain. The problems such as uncoordinated movement, injury and pain are not negligible in the exercise rehabilitation of middle-aged and elderly patients with coronary heart disease.

\section{CONCLUSION}

In middle-aged and elderly patients with coronary heart disease after $\mathrm{PCl}$, cardiopulmonary function, exercise ability and quality of life will be reduced to varying degrees if only conventional drug therapy is given, cardiac rehabilitation with exercise training as the core can effectively improve the cardiopulmonary function and exercise ability of middle-aged and elderly patients with coronary heart disease after $\mathrm{PCl}$, and also improve their quality of life to a certain extent. Compared with exercise training alone, it can better improve cardiopulmonary function and exercise ability of middle-aged and elderly patients with coronary heart disease after $\mathrm{PCl}$, the improvement of patients' physical pain, energy, emotional function, mental health and other aspects is better than simple exercise training, so it is suggested to be combined with clinical use.

\section{All authors declare no potential conflict of interest related to this article}

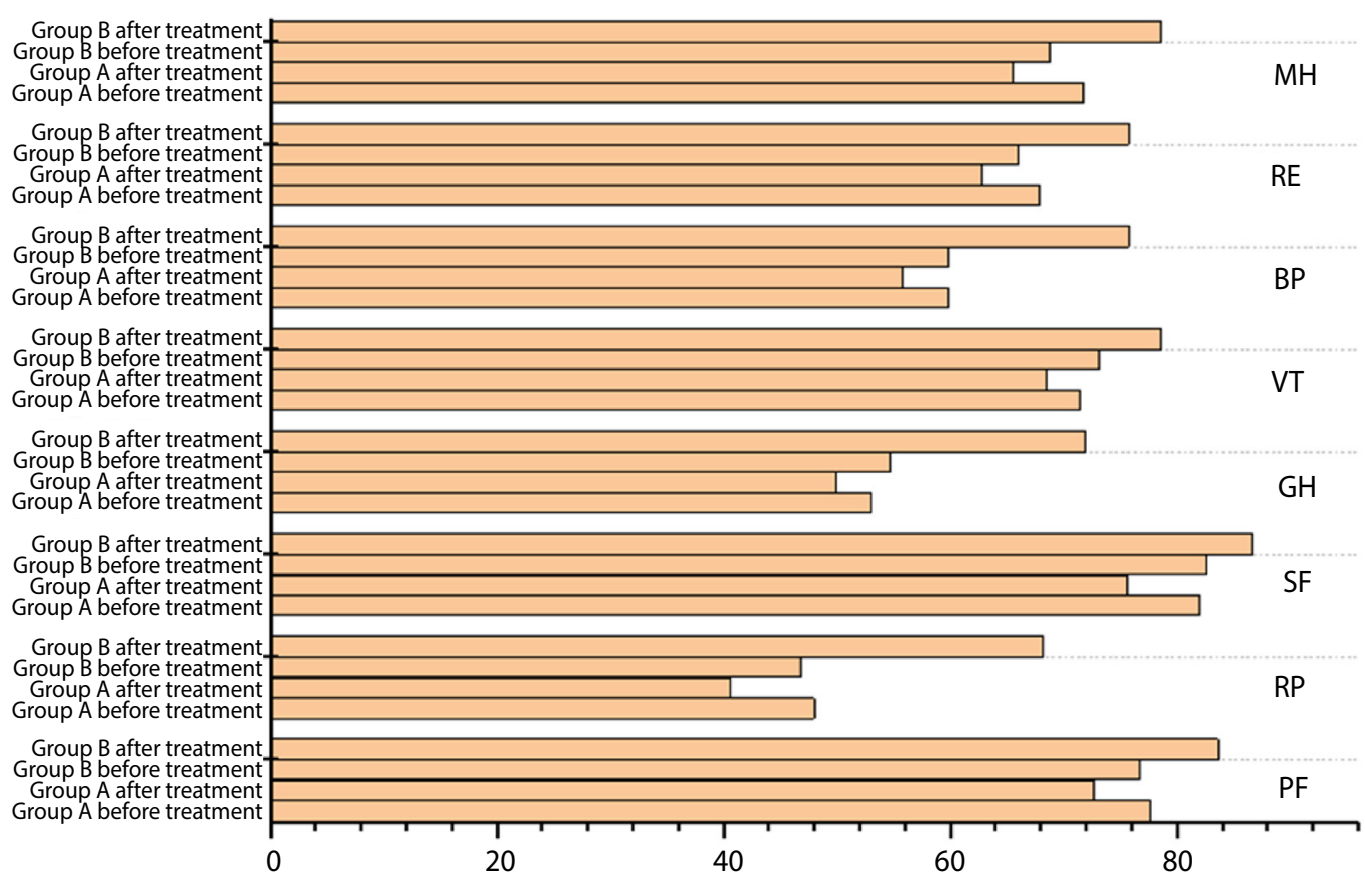

Figure 1. Health status of patients in each group with the Brief Health Status Scale (SF-36).

AUTHORS' CONTRIBUTIONS: Each author made significant individual contributions to this manuscript. Lili Lei: writing and performing surgeries; Jianchong Ma and Yongliang Wang: data analysis and performing surgeries; Weiqiang Hou article review and intellectual concept of the article.

\section{REFERENCES}

1. Duan FX, Wu Q, Zuo YF, Yang HX, Dai F, Wang L. Effects of mind-body exercise on cardiopulmonary function, blood pressure, and quality of life in CHD patients: A protocol for systematic review and
2. Kim K, Ahn N, Ju Y, Lee G, Kim M, Jung Y. Effects of Aerobic Exercise Training and Natural Fermented 
Vinegar on Body Composition and Cardiopulmonary Function in Middle Aged Women. The Korean Journal of Sports Medicine. 2018;36(3):126.

3. Zhang B, Cheng CS, Ye MG, Han CZ, Peng DY. A preliminary study of the effects of medical exercise Wuqinxi on indicators of skin temperature, muscle coordination, and physical quality. Medicine. 2018;97(34):e12003.

4. Tuan SH, Li MH, Hsu MJ, Tsai YJ, Chen YC, Liao TY et al. Cardiopulmonary Function, Exercise Capacity, and Echocardiography Finding of Pediatric Patients With Kawasaki Disease: An Observational Study. Medicine. 2016;95(2):e2444

5. Chen MC, Chen KM, Chang CL, Chang YH, Cheng YY, Huang HT. Elastic Band Exercises Improved Activities of Daily Living and Functional Fitness of Wheelchair-bound Older Adults with Cognitive Impairment. American Journal of Physical Medicine \& Rehabilitation. 2016;95(11):789-99.

6. Giallauria F, Vitelli A, Maresca L, Magistris MS, Chiodini P, Mattiello A et al. Exercise training improves cardiopulmonary and endothelial function in women with breast cancer: findings from the Diana-5 dietary intervention study. Internal \& Emergency Medicine. 2016;11(2):171-3.

7. Vainshelboim B, Kramer MR, Fox BD, Izhakian S, Sagie A, Oliveira J. Supervised exercise training improves exercise cardiovascular function in idiopathic pulmonary fibrosis. European journal of physical and rehabilitation medicine. 2017;53(2):209-18.

8. Jang YC, Park HK, Han JY, Choi IS, Song MK. Cardiopulmonary function after robotic exoskeleton-assisted over-ground walking training of a patient with an incomplete spinal cord injury: Case report. Medicine. 2019;98(50):e18286

9. Wang L, Zhu X, Zhao LP, Wang M, Liu X, Chen Y et al. Effect of beraprost on pulmonary hypertension due to left ventricular systolic dysfunction. Medicine, 2019;98(16):e14965.

10. Miao J, Wang L, Cui HT, Guo LY, Wang J, Lei JY et al. Study on the effect of integrated traditional Chinese and western medicine in the treatment of brucellosis. Zhonghua lao dong wei sheng zhi ye bing za zhi =Zhonghua laodong weisheng zhiyebing zazhi. Chinese journal of industrial hygiene and occupational diseases. 2021;39(4):253-7. 